2012

\title{
Senses of Sen: Reflections on Amartya Sen's Ideas of Justice
}

\author{
César Arjona \\ ESADE Law School, Ramon Llull University \\ Arif A. Jamal \\ Faculty of Law, National University of Singapore \\ Carrie Menkel-Meadow \\ Georgetown University Law Center, Center for Transnational Legal Studies, meadow@law.georgetown.edu \\ Victor V. Ramraj \\ Faculty of Law, Natioanal University of Singapore \\ Francisco Satiro \\ Department of Business Law, Sao Paulo University
}

Center for Transnational Legal Studies Research Paper No. 12-015

This paper can be downloaded free of charge from:

http://scholarship.law.georgetown.edu/ctls_papers/2

http://ssrn.com/abstract $=2008832$

8 Int'l J.L. in Context 155-178 (2012)

This open-access article is brought to you by the Georgetown Law Library. Posted with permission of the author.

Follow this and additional works at: http://scholarship.law.georgetown.edu/ctls_papers

Part of the International Law Commons, Jurisprudence Commons, Legal Education Commons, Public Law and Legal Theory Commons, and the Transnational Law Commons 


\title{
Review Essay \\ Senses of Sen: reflections on Amartya Sen's ideas of justice
}

\author{
The Idea of Justice \\ By Amartya Sen, London: Allen Lane, 2009. \\ $468 p p$. \\ ISBN 978-1-846-14147-8 £25.00 hardback \\ Reviewed by César Arjona \\ ESADE Law School, Ramon Llull University \\ Arif A. Jamal \\ Faculty of Law, National University of Singapore \\ Carrie Menkel-Meadow \\ Law Center, Georgetown University and University of California, Irvine Law School \\ Victor V. Ramraj \\ Faculty of Law, National University of Singapore \\ Francisco Satiro \\ Department of Business Law, Sao Paulo University
}

\section{Introduction}

The Idea of Justice is one of those books that - whether we agree with its ultimate conclusions or not will be virtually impossible to ignore. And for good reason: it takes on one of the great political philosophers of our time, John Rawls, and deepens, enriches and challenges some basic Rawlsian ideas. Sen's basic argument is that the Rawlsian approach to justice, which has profoundly influenced the development of contemporary political theory since the publication of $A$ Theory of Justice in I97I, is so focused on ideal, transcendentally just institutions that it is unable to offer practical guidance for advancing justice in an increasingly borderless world. Sen's ambitious critique of Rawls takes him on a winding but engaging path, through political and moral philosophy, economics, history and law. Along the way, he challenges mainstream economic theories of rationality, explores deontological and consequentialist ethics through the lens of classical Indian thought, articulates and defends an understanding of freedom in terms of capability, and rethinks the relationship between development, agency and democracy in a global context.

The genesis of this review essay is a reading group in which the five authors - whose qualifications and experiences span multiple jurisdictions and legal traditions - studied, discussed and debated Sen's text, in the setting of a nascent institutional experiment in transnational legal education, the Center for Transnational Legal Studies ${ }^{\mathrm{I}}$ in London. This essay takes the form of an

I The Center for Transnational Legal Studies is a freestanding programme of legal study for credit by the participating partner schools: see http://ctls.georgetown.edu. 
I56 CÉSAR ARJONA et al.

extended dialogue among its authors, whose varied experiences will, we hope, shed light on the multiple senses of Sen.

VICTOR V. RAMRA: Sen's book is refreshing and provocative in many ways, and even in limiting the scope of this part of the review to its implications for legal scholarship and legal education, I find much to say about his efforts to transform our thinking about justice in a transnational age. Indeed, Sen's attempt to broaden our understanding of justice while grounding that understanding on reason leaves his theory vulnerable to criticism from two directions. Some will agree with him that the Rawlsian conception of justice (and, for that matter, law) is inadequate, but will criticise him for retaining what they would see as a Eurocentric conception of reason in another guise, and they will urge a more thoroughgoing critique of a reason-based conception of justice. Others will argue that Sen has gone too far, abandoning any hope for a universal conception of justice. ${ }^{2}$ This is a critical tension in Sen's work and there is much to be said about it, but I want to leave this tension aside and reflect on three important aspects of his argument and the lessons they hold for law in a transnational age: his critique of transcendental institutionalism; his exhortation of comparative broadening; and his defence of pluralism.

Sen argues from the outset that the most serious problem with Rawls's theory of justice is its transcendental institutionalism. In the social contract tradition, Rawls's aim in his famous theory was to articulate a set of principles that would help shape the public institutions of a just society. Sen's criticism of Rawls is a simple but powerful one. 'A theory of justice that can serve as the basis of practical reason', he insists

'must include ways of judging how to reduce injustice and advance justice, rather than aiming only at the characterization of perfectly just societies - an exercise that is such a dominant feature of many theories of justice in political philosophy today.' (p. ix)

This is a criticism of the transcendental nature of contemporary theories of justice. In seeking a theory of justice for a perfectly just society, Rawlsian political theory becomes detached from reality: it does not give us a way of addressing social injustices from the Bengal famine of I943 that left millions dead to, one might argue by extension, the calamitous earthquake in Haiti in January 2010 that left over I50,000 dead and more than two million homeless. The response to these sorts of tragedies, argues Sen, is not to search for perfect transcendental institutions, but to prevent starvation and improve lives. And this can be done by affirming that preventing famines is the just thing to do even if we can't agree what form Haiti's government - or international development assistance - should look like. For Sen, what is important is our ability to make decisions about justice-enhancing and justice-reducing responses to particular problems, rather than being 'paralysed into inaction' (p. 395) because we disagree ideologically.

Assuming then that transcendental accounts of justice are problematic, how might we decide what justice requires in a given situation and what lessons this might have for legal thinking? To the former question, Sen offers two answers: first, we should look beyond our local, narrow, conception of justice ('comparative broadening' (p. I70)) and second, we should acknowledge that there may be more than one unique reason for acting in a particular way (a "plurality of sustainable reasons' (p. I83)). Consider first his response to parochialism. Sen concedes that it is not always easy for us to see beyond our 'positional perspectives' and that 'our very understanding of the world is so moored in our experiences and thinking that the possibility of going entirely beyond them may be rather limited' (p. I70). But Sen is not discouraged. Having demonstrated the

2 Sen might also be criticised for not engaging directly with Rawls's attempt (I999a; I99b) to extend his theory of justice as fairness to the international case. For more on this omission, see Jamal's contribution below. 
limits of rational, democratic, procedures for collective decision-making (by drawing on Kenneth Arrow (I96I) and the Marquis de Condorcet (I998)), he invokes Adam Smith, whose Theory of Moral Sentiments (I976) offers - in sharp contrast to the 'veil of ignorance' - a device for thinking about justice that draws our attention outward. 'In solitude', Sen quotes from Smith, 'we are apt to feel too strongly whatever relates to ourselves ... The conversation of a friend brings us to a better, that of a stranger, to a still better temper' (p. I25). Smith's impartial spectator provides us with a device 'for critical scrutiny and public discussion' which takes us beyond the 'institutional straightjacket [sic] of Rawlsian theory' (p. I35) and opens the door to a global dialogue about justice.

Sen's account of justice will inevitably be criticised for not offering a clear blueprint of justice to replace the Rawlsian account. But this criticism misses Sen's point: the first step in any fruitful discussion of justice is to 'de-parochialise' our own thinking:

'If the discussion of the demands of justice is confined to a particular locality - a country or even a larger region - there is a possible danger of ignoring or neglecting many challenging counterarguments that might not have come up in local political debates, or been accommodated in the discourses confined to the local culture, but which are eminently worth considering, in an impartial perspective.' (p. 403)

Sen seems to think, then, that by subjecting our views to broader scrutiny, we will find broader agreement on what to do, even if we still disagree as to why we do it.

Sen's exhortation of comparative broadening holds important lessons for legal education and scholarship. Although the past decade has seen several efforts around the world to take legal education beyond a narrow focus on domestic legal issues and doctrines, most law schools continue to teach domestic (or, in the case of the EU, regional) law, particularly at the level of first degrees in law, and rare are the instances of law schools that systematically expose law students to other legal systems or traditions. Slowly but steadily this is changing. An increasing number of law schools have become conscious of the need to look beyond their jurisdictional borders in order to understand a complex web of competing normative systems. The same can be said about legal scholarship. A growing number of law journals - beyond the niche area of comparative law (which has recently been subject to criticism for its narrow methodology (Mattei, I997)) - are dedicated to questions of transnational legality. ${ }^{3}$ And as Werner Menski (2006, p. xi; see also 2007) has recently observed, there 'has been growing recognition of the fact that academic activities in the complex fields of legal theory and comparative law remain underdeveloped and still too Eurocentric'. But as Menski also acknowledges (2006, p. 3), there 'is as yet little discussion about how globalisation relates to legal theory and understandings of law'. Mainstream legal research therefore continues, by and large, to analyse legal problems, offer solutions, construct theories and answer questions in ways that assume a Western legal context or take such a context to be the only appropriate normative yardstick. Sen's efforts to de-parochialise political theory - perhaps the most proximate discipline to legal theory - ought therefore to resonate with those in the legal academy who seek to reform legal education and shift legal scholarship away from its Eurocentric focus.

Opening ourselves to multiple ways of understanding what law or justice requires in a given situation might lead to nihilism, but Sen believes otherwise. In some situations, different conceptions of justice would recommend different courses of action (pp. I2-I5); but in others, we 'can have a strong sense of injustice on many different grounds, and yet not agree on one particular ground as being the dominant reason for the diagnosis of injustice' (p. 2). And this

3 See, for a notable example, the newly launched journal, Transnational Legal Theory (Oxford: Hart). 
'plurality of sustainable reasons' (p. I83) is sufficient in itself to act to reduce the injustice. So rationality and comparative broadening are linked: rational choice is 'primarily a matter of basing our choices - explicitly or by implication - on reasoning that we can reflectively sustain if we subject them to critical scrutiny' (p. I80); and it is through comparative broadening - subjecting our reasoning to the scrutiny of distant strangers - that we achieve the goal of critical scrutiny. It may be that this approach to rationality is 'permissive in that it does not rule out the possibility that more than one particular identification of what can be chosen with reason could survive a person's critical scrutiny', but this indeterminacy is presented as a strength, not a weakness, of the theory. Sen, like Smith, is wary of the tendency of some philosophers to look for a 'single homogeneous virtue' (p. 394).

There are some important lessons here for law and legal thinking. Sen's emphasis on plurality and the plurality of sustainable reasons in particular - is refreshing in two respects. First, as an empirical matter, the importance Sen accords to pluralism in the context of justice tracks the growing complexity of real-world problems and the plurality of legal regimes that seek to respond to them (Krisch, 20I0). Whether our concerns are commercial or environmental (to take two common examples that often intersect), the complexity of the legal regimes and norms that seek to govern these domains is polyvalent (Cutler, 2003, pp. I6-59). It is ever more difficult for legal advisors to give sound advice by reference to only one legal regime; increasingly a complex array of local, national, regional and international norms - many of which stand in tension with one another - must be taken into account. Second, as a normative matter, this complexity affirms the need for caution in the search for a single normative justification for transnational legal norms. Agreement, where possible, is important in as much as it facilitates collective action and interaction, whether on matters of trade and commerce or social justice; but the search for a unitary justification may well be elusive, and might prevent us from making progress in those areas where agreement is possible. Sen's indirect invocation of Voltaire rings true: the best may very well be the enemy of the good (Voltaire, 1772).

CÉSAR arjona: There is a Marxist dimension to The Idea of Justice. Philosophers and intellectuals should stop thinking about the world at an ideal level. Instead, they should work towards transformation, or, more humbly, to improve life's conditions. This is a bit more than an attitude: it makes up Sen's central ideas in his book. Instead of looking for the ideal conditions of a perfectly just society, social thinkers should aim at fighting injustice, no matter how partial and incomplete the fight might be. Instead of concentrating on just arrangements, on rules and institutions, social thinkers should focus on people's lives.

According to Sen, mainstream social thinking, including the social contract tradition, has for centuries adopted an approach that he calls 'transcendental institutionalism'. The Idea of Justice can be broadly defined as a general and profound critique of such an approach, and more specifically of its most recent version, provided by Rawls.

My co-author Victor Ramraj has concentrated on the 'transcendental' side of the approach. For my part, I concentrate on the critique of the 'institutional' side, which Sen distinguishes from a focus on actual social and individual behaviours and realisations. 'In the Rawlsian system of justice as fairness', writes Sen, "direct attention is bestowed almost exclusively on "just institutions", rather than focusing on "just societies" that may try to rely on both effective institutions and on actual behavioural features' (p. 67). According to Sen, Rawls is consistent with the dominant tradition in Western social thought that basically concentrates on institutions, instead of people's lives, as if the design and implementation of those institutions could be enough to achieve justice in practice. However, institutions are not justice in themselves, and 'we have to seek institutions that promote justice, rather than treating the institutions as themselves manifestations of justice, which would reflect a kind of institutionally fundamentalist view' (p. 82). Thus, even if institutions may be useful in 
fighting injustice, their success depends on various social, economic, political and cultural circumstances that are often underestimated in modern theories of justice.

Sen emphasises that mainstream Western social and political thought has missed the relevance of actual human lives and social behaviour in the pursuit of justice, as well as the real consequences that different actions and decisions have on people's lives. In relation to justice, both institutional arrangements and actual human behaviour must be taken into account. 'There is a two-way relationship between the encouragement given to rethinking behaviour on grounds of social justice and the institutional need to advance the pursuit of social justice' (p. I I I). There is indeed a mutual dependence between these dimensions, so that in order to be successful, institutional reforms require changes in actual social behaviour.

In my view, this has very direct implications for legal theory and legal education. On this, more later. But first it will be useful to consider a classical distinction in Indian ethics and jurisprudence on which Sen relies in order to clarify the problem of institutionalism: niti and nyaya. According to Sen, both terms stand for justice in classical Sanskrit. However, they refer to different dimensions of justice. Niti means 'organizational propriety and behavioural correctness', whereas nyaya refers to a 'comprehensive concept of realized justice ... which is inescapably linked with the world that actually emerges, not just the institutions or rules that we happen to have' (p. 20). A niti perspective is focused on institutions and the rules that make up these institutions, but if we want to know the real world in which we live (and the human suffering produced by injustice) we must supplement this perspective with a nyaya approach. The distinction between niti and nyaya is strikingly similar to another distinction, famous in Western legal thinking: law in books vs. law in action, as it was initially formulated by the American jurist Roscoe Pound (I9I0). ${ }^{4}$

One of the reasons a nyaya (law in action) approach is preferable to a niti (law in books) approach is that it leaves room to consider consequences. However, it would be a mistake to equate nyaya with a purely consequentalist approach to ethics and justice. A nyaya approach also takes into account processes, duties and responsibilities, as is exemplified in Arjuna's episode in the Gita, a recurrent story throughout the book. This is the reason Sen insists on the concept of 'comprehensive outcome' which includes the processes involved, and which has to be distinguished from just the 'culmination outcome' (p. 22). In his essays on eunomics, the great American jurist Lon Fuller pointed out the dangers of disentangling means from ends in social and legal analysis (200I). Sen confirms that such a divorce results in an impoverishment in the theories of justice. In short, a nyaya approach does not amount to the adoption of consequentialism (although it takes consequences into consideration).

However, a nyaya approach clearly points to the inclusion of an anthropological element in the theory of justice. There is an emphasis on the human element throughout Sen's book, revealed in the many stories he uses to illustrate and explain different points. Some of these stories come from ancient history, others from contemporary times; sometimes they are real, sometimes fictitious; but they are always human stories. Certainly they add colour to the book, but they are much more than a decorative element. This anthropological sensitivity occupies a central place in Sen's conception of justice: 'the pursuit of a theory of justice has something to do with a similar question: What is it like to be a human being?' (p. 4I4). Of course, knowledge of human nature is not enough to answer each and every question involved in a theory of justice, but Sen emphasises that underlying many of the rival theories of justice is a common conception of what a human being is. And the main features of this common conception are the willingness to fight against

4 The distinctions do not have exactly the same meaning, but there are obvious and interesting similarities between them. Incidentally, this illustrates one of the many values of Sen's work: to show that ideas that are believed in the West to be original were already important in other areas of the world in ancient times. 
injustice and the disposition to do so by engaging in public discussion: 'to reason, argue, disagree and concur' (p. 4I5).

In fact - and this is, in my view, one of the most important values of this work - Sen himself illustrates these human qualities. As is made explicit in many parts of the book, Sen finds the motivation to undertake his grand intellectual task in his perception of injustice and human suffering. He is moved to fight injustice, and he does so through the process of engaging in an open public discussion: describing, analysing, praising and criticising different theories, policies and paradigms ranging from virtually all fields of social thought. This is related to Sen's biography. At a very young age, Sen experienced terrible examples of injustice, such as identity confrontations in India that resulted in a great deal of violence, as well as the tragic Bengal famine of 1943 in which between two and three million of the lower classes died. In his autobiography (1999), written for the occasion of his receipt of the Nobel Prize in Economics, Sen acknowledged that most of his fields of work had already been among his concerns as an undergraduate student. And reading the facts of Sen's life one finds over again the main subjects dealt with in The Idea of Justice. 5

Closely related is the fact that Sen grants to emotions and instinctive sentiments an important role in the search for justice. Nevertheless, he does not question the primacy of reason as the crucial element in the theory of justice. In fact, from the very beginning Sen makes clear that if we want to take part in the enterprise of building a theory of justice then we must engage in reasoning (p. 5). But reason is a broad concept that can leave room for emotions, and Sen acknowledges that cool calculation is not necessarily the best way to approach ethical problems (p. 49). Among other things, emotions are significant as a motivational force in the pursuit of justice: Sen states that outrage can be an important motivation (although not a replacement) for public reasoning in the field of justice: 'what tends "to inflame the minds" of suffering humanity cannot but be of immediate interest both to policy-making and to the diagnosis of justice' (p. 388).

As Victor Ramraj notes at the opening of his contribution, some may criticise the fact that, in spite of his concessions, Sen still gives primacy to reason, thus defending a Western-like reason-based conception of justice. ${ }^{6}$ This is a very difficult and profound debate, but let's not forget that Amartya Sen is the winner of the Nobel Prize in Economics, and one of the most widely read thinkers in this all-rational discipline. I would say that those who are critical of Sen's emphasis on reason should appreciate his devastating critique of contemporary mainstream economics for assuming a conception of human reason that Sen finds extremely limited. This extensive critique - Sen devotes almost the whole of Chapter 8 to it - is based on three pillars: (I) people do not always act rationally; (2) reason does not always point to a single decision, since there may be a plurality of sustainable reasons or arguments; and, most importantly, (3) acting rationally does not mean pursuing one's own self-interest. Sen criticises the fact that the discipline of economics is dominated by the untenable assumption of the completely egoistic human being, and acquits Adam Smith from ever having believed in such a poisonous principle. ${ }^{7}$

5 In this regard, there are striking similarities between the life of Sen and that of another Nobel Laureate, Muhammad Yunnus. While professor of economics at the university of Dhaka (where Sen's family is originally from), Yunnus was outraged by the pervasiveness of poverty outside the campus. Impatient with the unwillingness of both university professors and bankers to challenge the principles of mainstream economics that condemned millions to deprivation, Yunnus decided to act. He became the forefather of microcredits and founded the Grameen Bank, which has worked successfully towards improving the living conditions of poor people, particularly women (see Yunnus, 2003). Yunnus and the Grameen Bank jointly received the Nobel Peace Prize in 2006.

6 See Carrie Menkel-Meadow's contribution below.

7 See Sen (2010), commenting on Adam Smith's double legacy contributions to economics in The Theory of Moral Sentiments (I759) as well as The Wealth of Nations (I776). 
SENSES OF SEN: REFLECTIONS ON AMARTYA SEN'S IDEAS OF JUSTICE $\mid$ I6I

The importance of the critique lies not only in its content, but also in the authority of the critic in the field of economics. However, this is not a book about economics but a book about justice, and it reaches as far as the field of law and jurisprudence. Indeed, the approach advanced by Sen has obvious implications for legal theory and legal education, at least as long as they are understood in connection with the idea of justice. Thus, going back to the niti/nyaya contrast, it is difficult to avoid the impression that legal education is generally controlled by a niti approach. In particular, the dominant method of legal education in continental Europe - what we could call the dogmatic method - is quite a radical version of the niti approach. In this method, the educational goal is to acquire as much knowledge as possible, primarily of the text of written rules, and secondarily of judicial decisions that deal with those rules as well as the shape of the institutions that are created by those rules. This rather acritical approach is responsible, to a great extent, for a dehumanising tendency in law schools, since it leaves out the different human behaviours implied by those rules. In Sen's language, there is an important deficit of nyaya in this field.

Of course the situation is markedly different in other legal education systems, particularly the American system, which influences many others worldwide. In my view, this is related to the history of American legal thought, and here the similarity between Sen's nyaya and Pound's law in action is quite relevant. Indeed, Pound's felicitous expression was taken as a slogan by the influential school of American legal realism, which during the twentieth century substantially changed the way in which law is taught in the United States, leading, for example, to the widespread use of clinical legal education, mooting and improvements on the case method (see Summers, I982; Fisher, Reed and Horwitz, I993, especially chapter 8; Wilson, 2009, describing the resistance in continental Europe to the adoption of clinical legal education). Of course, none of these elements guarantees by themselves an increased awareness of questions of justice, but at least they offer an opportunity to consider the human element that the dogmatic method excludes altogether. As Sen convincingly shows, at the end of the day, injustice has more to do with human lives and social realisation than with the rules written in books.

The other side of the dogmatic method consists in identifying the legal system with the local norms produced by one state (and secondarily by the agreements among different states). In its most orthodox version, this dogma affirms that the law and the state are one and the same thing (Kelsen, I945). I agree with my co-author Victor Ramraj in his diagnosis of legal education as for the most part narrowly focused on domestic issues. Indeed, this dogma is so pervasive that, using Thomas Kuhn's (I962) framework, it has been considered the basic principle of the dominant paradigm in contemporary legal science (van de Kerchove and Ost, I987).

Sen's approach to justice implies the rejection of this dogma not only as institutionalist (because the state is an institution, and this links with the previous problem of the niti approach), but also as exclusionary. With regard to justice, domestic local perspectives are limited in at least two ways. First, the nature of injustice in our world is often global, and the national law is too narrow both as a perspective from which to contemplate and analyse it and as a tool to fight against it. Second, an exclusive focus on national law discards perspectives from abroad, condemning the legal field to parochialism, and this is one of the elements that most obstinately obstructs the fight against injustice. This point links with Sen's emphasis on comparative broadening and his constant reference to the 'impartial spectator'. In any case, I believe that Sen urges legal education to include many more comparative, international and, crucially, transnational perspectives, the result of which might be to produce a (probably radical) transformation of Western legal education.

This leads to a more general point that goes beyond the area of legal education. Those who want to emphasise the crisis of the nation-state as the institution that has controlled the field of law and political theory for centuries will find in Sen's book strong arguments supporting their position. Its emphasis on the global dimension of social and ethical problems seeks to surmount international approaches, since 'the demands of global justice may differ substantially from those 
I62 CÉSAR ARJONA et al.

of international justice' (p. I40). In my view, the crucial point here is that we do not need to build a global state in order to have global justice (p. I4I). This approach is full of hope and optimism, because there is no plausible global state round the corner, whereas problems of injustice are urgent and pressing. But public discussion can advance democratically without a global state. In fact, and to a certain extent, global democracy is actually happening already. But of course, this optimistic approach is only justified once we adopt a non-institutionalist nyaya-conception of democracy, in which 'democracy is no longer seen just in terms of the demand for public balloting, but much more capaciously, in terms of what John Rawls calls "the exercise of public reason”' (p. 324).

FRANCISCO SATIRO: The Idea of Justice is sustained by several arguments that Sen has already developed in other works. His criticisms of Rawls's A Theory of Justice, as well as instrumental rationalism, and equality as the basis for every social justice theory, for example, are basic elements of the book's conclusions that he has already explored, as are the celebration of human heterogeneity and the need to consider institutions from a global perspective. Moreover, since the book explores some complex ideas rather briefly, the constant references Sen makes to his other writings have the effect of complementing his arguments. At various places, consulting these texts on the points discussed clarifies positions urged by Sen that might be left cloudy by a simple reading of the book.

Because of Sen's extensive previous output, it is no surprise that The Idea of Justice is more of a mature convergence of previously tested ideas in search of a satisfactory 'path' to reach justice than a creative explosion of new ideas. This search for a 'path' is perhaps one of the main points of his work: Sen leaves aside concern with defining the concept of justice itself, instead indicating what he considers necessary to promote specific advances toward justice.

Sen makes frequent references to John Rawls, certainly the main contemporary thinker on the theory of justice. Indeed, Sen reveals his close ties with Rawls by recounting that in I969 he had the opportunity to teach a joint graduate seminar at Harvard on political philosophy with Rawls and Kenneth Arrow (who came to win the Nobel Prize for Economics in 1972 for his work on social choice theory), for which the manuscripts that gave rise to A Theory of Justice were used as teaching material. For this reason, Sen begins the second chapter - which he dedicates almost exclusively to explaining the concepts of that book - by praising Rawls and recognising him as among the leading lights in developing modern theories of justice. But this does not stop him from strongly criticising the assumptions of Rawlsian theory in the rest of the book. This is nothing new: Sen has long been expressing his opposition to the transcendental institutional basis of Rawls's theory (see Sen, I985, pp. I Iff.).

It is significant that, as the title of his book suggests, Rawls proposed to build a comprehensive 'Theory of Justice'. In one of the most traditional explications of 'theory', Karl Popper (2002, p. I7) described it as an essentially rational concept that explains a phenomenon and is able to withstand the test of facts. What Sen demonstrates is precisely that the facts do not support Rawls's theory. The model of justice based on fairness and transcendental institutionalism, limited by comprehensive principles proposed by Rawls, is too abstract and general, and as a consequence is of little use. From a transcendental point of view, institutions moulded according to the abstract concept of justice are based on a standard of behaviour and values distant from the reality of the individuals to which they apply.

In analysing the (in)sufficiency of Rawls's transcendental concept of justice, Sen questions whether it is possible to take it as anything more than a sophisticated 'intellectual exercise'. In an inspired analogy, Sen criticises a focus on the exploration of universal models by saying that 'the fact that a person regards the Mona Lisa as the best picture in the world does not reveal how he would rank a Picasso against a Van Gogh' (p. Ior). According to Sen, the usefulness (p. IO2) of establishing a central and definitive concept of justice is questionable because it demands a huge 
SENSES OF SEN: REFLECTIONS ON AMARTYA SEN'S IDEAS OF JUSTICE $\mid$ I63

intellectual effort, at the cost of generalising concepts, and in any event, because of the 'basic heterogeneity of human beings' (see Sen, I993, p. I), it might not be sufficient to solve real problems and conflicts. The paradox rests exactly in the fact that to create a sufficiently objective and universal model, Rawls wound up sacrificing the rich panoply of values held by individuals, interest groups, nations, etc., and assumed that all of these can be adjusted to a single theoretical framework:

'I am arguing for the possibility that there may remain contrary positions that simultaneously survive and which cannot be subject to some radical surgery that reduces them all into one tidy box of complete and well-fitted demands, which, in Rawls's theory, take us to some unique institutional route to fulfill these requirements (to be implemented by a sovereign state)'. (p. 46)

Sen recognises the difficulty of attaining global justice, especially because of the many cultures, principles and values of different peoples, so there can be no set formulae to resolve the problem. But it is from this observation, and the relative uselessness of the general and abstract concept, that Sen develops his proposal to switch from the search for a universal concept of justice to the fight against injustices.

What at first appears simply to be the other side of the coin is in reality an intriguing proposal, especially interesting when dealing with social injustices. After all, injustices are much easier to identify (in certain cases even instinctively) and tend to generate counter-reactions naturally. It is necessary, however, to treat first impressions cautiously. Sen energetically advocates the indispensability of reasoning, as already mentioned by my colleague César Arjona. But the importance of feelings and emotions should never be ignored. Based on the ideas of David Hume (I978), Thomas Nagel (I997), and particularly on The Theory of Moral Sentiments by Adam Smith, Sen recognises the impossibility of ignoring the influence of feelings on human attitudes (p. 50).

But sentiments alone are not enough to lead to desirable results, both because they are subjective and have origins that are hard to identify and because they vary and are restricted in function by the personality of their agent, or his connection with a certain circle of people or group, etc. Even if feelings alone by chance lead to the enhancement of justice, it will be a sterile process that can hardly serve as a basis for new processes. For results to be effective, and in reality to lead to the construction of a more just society, emotions must be tempered by reasoning (p. 39). To use emotions as a signal it is necessary to try to understand what lies behind them. This requires critical scrutiny (p. viii).

Sen rightly stresses that 'unreason' does not simply mean acting without reasoning, and instead may imply relying on 'very primitive and defective reasoning' (p. xvii). But he also refers to situations where weak and improper reasoning is developed simply to legitimise emotional behaviours, or where empty reasoning is created solely to make an unreasoned argument appear rational. This is what happens in the case of oppressive political regimes such as dictatorships, or the rules on racial and religious segregation that still hold sway in some regions. Sen believes that in these cases the only real solution is to build consistent reasoning that confronts the prevailing dogmas and prejudices, exposing their fragility.

The reasoning behind a fair decision must withstand public scrutiny, hence the central importance of public reasoning to combat injustices (p. I22). In the light of the diversity of impartial positions, Sen states that 'when we try to determine how justice can be advanced, there is a basic need for public reasoning, involving arguments coming from different quarters and divergent perspectives' (p. 392). The framework for public reasoning necessary to build justice from a comparative standpoint is the 'theory of social choice', which Sen thoroughly explores in the fourth chapter. With this instrument it is possible to think of developing justice that is not 
I64 CÉSAR ARJONA et al.

restricted to a single state, community or group of people. Moreover, the process of fighting injustices and its underlying reasoning must be made public: 'justice being seen to be done' (p. 392) not only for instrumental reasons, but to guarantee public soundness.

Despite the complexity of the supporting arguments, the book has an unmatched simple core point: there are situations of extreme injustice that demand immediate attention, and the quest for the 'Holy Grail' of the ideal concept of Justice may not help to achieve this within the short term. In The Idea of Justice Sen demonstrates that, far from being just an economist, he is a philosopher, a social thinker concerned with placing his intellectual abilities at the service of reality. The commitment to a better world, by reducing inequalities and social differences, is present on virtually every page, as is his belief in the feasibility of achieving the objectives of justice in a setting of global political, religious and cultural diversity. It is hard to disagree with Sen's objectives, and this makes the book an argument for optimism, even though it leaves many questions still to be addressed, such as the problem of social choice in the face of plurality. But there can be no doubt that the book asks serious questions about transcendental institutionalism and offers a powerful argument against impassivity in the face of injustice, an antidote to what Blaise Pascal (I958, p. 85) once prophesied: 'We must then combine justice and might, and for this end make what is just strong, or what is strong just.'

CARRIE MENKEL-MEADOW: What Sen speaks to most profoundly in The Idea of Justice is that justice is more than 'an' idea, of perhaps universal and transcendental significance as other political philosophers have argued. Instead of focusing on conceptions of perfectly just or ideal societies, Sen asks us to focus on ways to 'remove manifest injustices' (p. 21). ${ }^{8}$ Justice is, for Sen, both more than an idea - it is lived experience of how we are treated and how we see others being treated - and, it is many ideas, if we take seriously his notion of comparative assessments of actual configurations of human conditions, institutions and capabilities. To illustrate, consider the parable of the single flute and the differently abled, entitled, and needy children (pp. I2I5). Anne knows how to play the flute already, Bob is so poor he has nothing else to play with at all, and Carla has made the flute with her own labours - who may 'justly' claim the flute? Sen uses this story (and many stories of real injustice in the world) to elaborate on the inadequacies of most traditional theories of justice, including Rawlsian 'veils of ignorance' or 'difference principles' that have so captured twentieth-century political philosophers of certain rational and 'liberal' (individualistic and neutral) bent.

Since my co-authors in this review have said more about his profoundly helpful turn in moving us towards more realistic discussions of what less injustice would be, I want to take up the challenge of several important issues that Sen raises but does not fully develop. Let me make one thing clear, however, as I focus, as many reviewers do, on what is missing in the book under review: Amartya Sen has, in my view, contributed a classic in both political theory and jurisprudence (as an economist no less!), which we will be teaching, reading, analysing and elaborating on in the decades to come. His is a profound move, and a gentle - but I think ultimately a more damaging and fatal - challenge to all that has come before in the way of overly abstract theories of justice.

8 In this way Sen aligns himself with a series of political philosophers who were more concerned with 'removing manifest injustice' than imagining a 'perfectly just society'. Whether it is appropriate to dichotomise a group of 'positive' justice theorists (social contractarians, European Enlightenment, utilitarian, and generalist political philosophers, like Hobbes, Locke, Rousseau, Kant, Bentham and Rawls) from a more 'negative' injustice revealing group (Adam Smith, Condorcet, John Stuart Mill, Mary Wollstonecraft and Marx), Sen clearly attaches himself to the latter group, describing his 'ideas of justice' project as a 'Smithian' one (aligning himself with the work of economist Adam Smith's 'other' great work, The Theory of Moral Sentiments), continuing in the vein of being a 'moral economist' (Sen, 2009). 
SENSES OF SEN: REFLECTIONS ON AMARTYA SEN'S IDEAS OF JUSTICE $\mid$ I65

What real political, legal or social institution has actually been founded on the basis of Rawls's concepts? What possible solutions to world hunger does Sen offer us? (Several!) 9

I write here about some issues suggested for further treatment by my co-reviewers. Here I am concerned with several matters: (I) what kind of discourse - public, private, global, domestic, democratic or intellectual - are we 'capable' (Sen pun absolutely intended!) of having, to make a world of less injustice, in the absence of total agreement about the ends, goals or 'good' for which we aim; (2) the role of emotion, empathy and feeling in this discourse, which Sen wants to include in his conceptions of rational discourse, but ultimately folds back into a more rationalised and conventional discourse; (3) the role of lived experience, narratives, stories, anecdotes and statistics (empiricism) in these discourses; and finally (4) the implications of Sen's work, this book, and these comments, for how we think and teach about justice, particularly for these reviewers, in a transnational legal programme where students and faculty, from many different nations, backgrounds and cultures, grapple collectively with these issues.

Sen begins by telling us that we can see injustice even when we haven't fully experienced justice. This could be the old saw 'I know it when I see it' (applied to American constitutional doctrine on pornography), or more likely, that injustice is felt (experienced as an empirical matter) and may have more causes than simply 'unjust or sub-optimal institutions'. Much injustice will be, in his terms, behavioural, structured by individuals and groups interacting with each other, and may or may not be subject to the possibility of institutionalised restructuring. And, most importantly, if we aim for 'transcendental' or universally 'just' institutional arrangements (or transcendental institutionalism) to guarantee fairness and justice (even assuming we could get some definitional clarity on whether we are looking at equality, equity, distributive or substantive forms of justice), we may be looking too skyward to see what is happening, quite literally, on the ground. While the philosophers are busy thinking or dreaming of imagined desiderata of just institutions, real policy-makers have to make choices, and real people have to live (and perhaps die) with the consequences of those choices.

Sen's second move is to diversify the sources of our theories, concepts and data. He asks us to change our basic methodology from looking for ideal specifications of justice to realisation focused comparison (pp. 7-I9), a form of public discourse focusing on empirical comparisons intended to improve the conditions of real people (which includes elements of utilitarianism, economics and recent work in deliberative democracy and social choice). Even granting some need for conceptual clarity and teleological discussions of what justice is, too much of modern 'Western and Northern' discussion has focused on a few classical Western and Northern political philosophers from Machiavelli to Locke, Hobbes, Rousseau, Kant, Mill, Bentham, Marx and, most recently, Rawls and Dworkin. What do Buddha, Manu (I99I), Akbar (Habib, I997), Asoka (Smith, I909) and Krishna (Dharma, I999) ${ }^{\text {Io }}$ have to tell us about an Asian informed sense of consequentialism and the important relationship of processes to outcomes (see generally Sen, 2005)? ${ }^{\text {II }}$ If Rawls (especially in his later work, The Law of Peoples (I999b)) and his critics think that both discourse about, and

9 Sen suggests that no grand theory but better systems of distribution would move food around more justly and efficiently, and that educating more people (a simple idea to think about but hard to implement in practice) would enable such distribution systems to be operated. (As a recent illustration of this situation, consider the global mobilisations in times of natural disasters - wealth and grand theory were no guarantors of just distribution of food, shelter and goods.)

Io I should confess that this was required reading in my college studies in the I960s.

I I So I must also confess, as a professed 'process pluralist', and multidisciplinarist, that I found Sen's descriptions and embraces of a variety of both intellectual processes and disciplines (economics, sociology, religious study, game theory, as well as political philosophy) and forms of democratic processes (rational choice, voting theory, engagement with values and feelings) most congenial to how I look at and teach about issues of justice (and peace) (see Menkel-Meadow, 2006a). 
achievement of, institutions of true global justice are impossible in our current state of diversity, multiculturalism, lack of agreement on human goals and ends, not to mention wars, natural disasters and mass displacement, then how can we possibly talk about global justice? This is where my colleague César Arjona left off and where I propose to pick up the conversation.

Sen, like many modern political philosophers who deeply believe in democratic selfdetermination, urges that we can still use REASON to at least reduce or ameliorate injustice in the world, even if we can't use a single idea of justice to achieve an ideal of justice. Sen explores some, but not all, of modern discourse theory to offer some methodological or procedural ways around the 'substantive justice' problem. He offers discussions of rationality, using objectivity and Adam Smith's trope of the 'impartial spectator' to give us distance, and of the omnipresent claim of philosophers for the need for some neutrality (recently contested again by Michael Sandel (2009)) in the making of our choices. In a major contribution to the study of rationalism, Sen describes clearly for the more general reader the mathematical and game-theoretic insights of how decisions based on so-called reasonable choices and democratic voting are subject to a variety of distortions (Condorcet's paradox, Arrow's theorem, plurality voting, incommensurability and the like (pp. 87I I I, I55-207)), that make universally selected choices almost impossible, even if ordinal valuing and comparisons are sometimes possible. Sen urges us to consider comparative choices for evaluating better, not best, outcomes, and he hopes to provide rigorous tools for that discourse to occur.

So, while I applaud his discussion of reason, voice and social choice, I have more trouble with his notions of impartiality (even when modified by the phrase 'open') and objectivity (even as modified by his more diversified notion of objectivity (Harding, 2003)), and particularly his descriptions of the practice of democracy. ${ }^{12}$

Sen refers to Habermas (pp. 324-27ff.) as a theorist who believes we can talk our way into some agreement about how to make political choices, with proper and inclusive participation, and representation of our human diversity. I am a bit surprised by the absence in this discussion of a reference to fellow social philosopher Stuart Hampshire, who expressed the hope that properly inclusive reasoned discussion can lead us to more just choices. Like Rawls, Sen and other disillusioned moral and political philosophers, Stuart Hampshire concluded, near the end of his career in his Tanner Lectures (200I), that while we were unlikely to reach agreement on the 'substantive good', we could probably agree on proper procedures for deciding on our human goals, such as audi alterum partum (hear the other side). Hampshire's lectures outlined the importance of adversary debate and reasoned argument, and, like Sen, he wants us to really listen and hear 'the other' side. We can hope for understanding, sympathy, maybe even empathy, if not total agreement, with those with whom we disagree or from whom we have not heard before. Thus, talk, conversation, dialogue and taking 'the other' seriously are essential in making our political choices. Although I have criticised Hampshire for seeing only two sides to what are often multi-sided issues, and for failing to develop a model of democratic discourse (closer to Habermas's) that includes these many sides, there is some convergence in the work of recent discourse theorists in seeing that process, analysis, comparison, rigorous data-gathering, wellstructured discourse, and broader social participation will get us more concrete, diversified and better solutions to some of our particular problems of injustice.

But like Habermas and Hampshire (and others that have gone before: Gutmann and Thompson, I998; 2004), Sen, in my view, still relies too much on a conventional and overly cognitive sense of what it means to use 'reason' for a discourse to allow us to make social evaluations and accomplish human problem-solving. Although he pays lip service to emotion and feelings (with

I 2 Other reviewers have already faulted this work, as others in the vein of democratic discourse theory have been critiqued, as simply 'talk, talk, talk'. 
appropriate references to some of the leading theorists such as Adam Smith (I976) and feminist philosophers like Martha Nussbaum (200I)), there is not enough discussion of the role of feelings, emotions and experience of those unjustly treated for this reader, theorist and teacher.

I have argued that for democratic deliberation really to work we need to take account of different kinds of discourses: first, those privileged by political philosophers (and most lawyers and legal theorists): reason and principle; second, the discourse of bargaining, negotiation and trades (an instrumental discourse grudgingly recognised by economists and a few political theorists, e.g. Jon Elster (I995); see also Menkel-Meadow (2006b)) - more practical, but necessary for actual agreements; and finally, claims made on the basis of emotions, values ${ }^{\mathrm{I}}$ and feelings (MenkelMeadow, 2004-2005). If reason occurs in the brain, and emotions and values are felt in the heart or 'gut', then we need our mouths to form the discourse of a negotiation that will enable us to hear all that must be said in order to make choices about policies in inclusive, democratic and injustice-diminishing ways. The whole 'body' politic (not just the 'brain') may be necessary for truly pluralist dialogue and decision-making.

Sen says we will need 'reasoned scrutiny from different perspectives' (p. 45) to ensure ethical and political objectivity or legitimacy for the choices we make. I want to suggest that the different perspectives include not only the kinds of deliberators (different classes, genders, ethnicities, nationalities) but also the kind of deliberation, since, for many, conventional reason (rational principle) is not the only way we make decisions.

Indeed, Sen himself has acknowledged that what is most likely to move people to do something about injustice is anger (2009). Thus, any modern theory of justice which turns on the importance of democratic deliberation or discourse (and we are generally in a period of procedural theories of justice in reaction to an inability to mediate and agree on a universal or single substantive idea of justice) must take account of the different ways in which people try to persuade each other. ${ }^{14}$

Philosophers and academics prefer to focus primarily on reason, but Sen's own method belies his claims for a purely principled reasoned argument succeeding. He masterfully reviews (pp. 9I-II3) the mathematics of social choice theory and public evaluation through the distortions of virtually any voting scheme (in Condorcet's paradox of the inconsistency of majority voting for ordinal preferences, and Arrow's impossibility theorem). ${ }^{15}$ He recognises that even with improvements to availability and sources of information, voting and elections will not get us optimal outputs, especially in environments where there may be many suboptimal choices, no purely optimal choice, and yet choice(s) must be made. Such choices could include selecting multiple simultaneously operating choices: consider, for example, educational vouchers operating in conjunction with public education systems. ${ }^{\text {I6 }}$

Multiplicity of perspectives gets us more possible choices (two heads are better than one?) and then we can use comparisons, in various domains of human 'reasoning', to evaluate a variety of different approaches. Consider, from my own field of feminist theory, the debates about whether

I3 'Values' are clearly the most divisive and difficult discourse to have, since it can include not only ethical and moral values, but religious and other 'identity' and group-based values. Value dissensus is acknowledged by deliberative democrats and conflict resolution professionals to be the most difficult, but not impossible, sphere of discourse across differences (Forester, 2009).

I4 Sen says that the social choice that he favours as a discipline is 'concerned with arriving at overall judgments for social choice based on diversity of perspectives and priorities' which includes 'diverse rankings yielded by different types of reasoning' (p. I09).

I5 Topics which every modern law student should be studying, in my view, as crafters of constitutions and code sections, but, more importantly, as those who manage meetings, people, organisations and corporations, and as those who advise other people who do these things.

I6 In the United States, these represent government support of private educational choices, used particularly in the value-based sphere of seeking special schools by subject, ethnic, class or other groupings. 
substantive equality is best achieved through total gender integration of all institutions (education, army, etc.) or whether some tolerance or promotion of difference (single-sex schools) might be better for some (the greater likelihood of flourishing in 'safer' environments). Pluralism of outputs (with subsequent analysis of efficacy of outcomes) is more likely to emerge with a diversity of ideagenerators, as well as with processes that are respectful (and diverse) enough to acknowledge different ways of creating, evaluating and choosing ideas. For some this will be conventional 'reason'. For others this will be the experience of pain, mutuality or reciprocity, care, sympathy or empathy. ${ }^{17}$

As voting and elections will not guarantee us perfect outcomes, neither will reason alone. Sen tacitly acknowledges this by allowing that emotions should play some role in deliberations about social choices, but most importantly, Sen uses this method himself when he recounts moving stories of hunger, racism, torture and medical need (as did Ronald Reagan when he artfully governed by 'anecdote') $)^{18}$ to persuade us to think about injustice, using both individual stories and the power of 'statistical narratives' (see, e.g., his discussion of health conditions in Kerala and morbidity differences related to women's education, pp. 164-67; the story of the Good Samaritan, pp. 170-72; the Arjuna-Krishna debate as an appeal to reason, emotional conceptions of duty and the justness of fighting a war, pp. 208-217; the relation of disability to poverty, pp. 258-60; and the role of information and democracy in the Bengal famine of I943, pp. 339-45).

In these examples, as in others, Sen appeals to our sense of reason, the need for a language of choice and trades (bargaining) among choices, and the metrics of emotion and values in those choices. He knows we are best persuaded by appeals to our multiple senses of knowledge and evaluation. Trades are often instrumental and emotions are not 'irrational' (it is understandable if we are sad when we lose someone, angry when someone takes something, and caring when someone needs us), so we use many modes of discourse when engaging in social, political and individual choice. As Sen has successfully peeled back the limits of Rawlsian quests for the 'perfect' society, our next project, not fully explored by Sen, is how these different discourses can actually be used together. If we are to use the techniques of empiricism and social choice comparisons then we will need to use and understand data, incorporate our feelings, look for advantageous trade-offs to actually consummate deals and make decisions, and include great diversity of important values. ${ }^{19}$ How are we to do all this when we don't even agree about what justice is?

Sen, like many modern political philosophers mentioned above, and others, ${ }^{20}$ sees an answer in a process of 'government by discussion' (p. 324), which, as I have critiqued above, is described as a process of 'public reasoning' (focused a bit too much on conventional reason, argument and debate as the primary process) which comes a little too close (for this reader) to a 'transcendental' or more 'universal'21 process. Why can't/shouldn't public discourse be as plural as substantive

I7 Scientific studies of creativity report many different sources in many different spheres: see Weisberg (2006).

I8 Ever since President Reagan brought several American 'heroes' to attend the State of the Union address to Congress (televised to a whole nation), every President, regardless of party, has continued the practice of having a human being present to dramatise a particular policy objective for which the President seeks Congress's and the people's approval.

I9 Sen does take on the now explosive question of whether some cultures are just too 'different' to join this diversified but still Euro-rational project of justice (pp. 333-35).

20 Including the not so modern Walter Bagehot and John Stuart Mill.

2I Sen does an admirable job of excavating the history of democracy, suggesting that while modern forms seem Western and Northern, there are early precedents in ancient India, implying a sort of universal desire for 'participatory decision making' (in decisions that affect the people who are impacted by political decisions) (pp. 32I-23). This is most recently demonstrated in the 'Arab revolutions' of the spring of 20II, demanding great participation by the polity in a wide variety of Middle Eastern and North African societies. 
SENSES OF SEN: REFLECTIONS ON AMARTYA SEN'S IDEAS OF JUSTICE $\mid$ I69

political outcomes for the reduction of injustice? In his crucial chapter on 'Democracy as Public Reason' (Chapter I5), Sen acknowledges this broader conception of democracy beyond elections and balloting, prevalent in scholarship today - public discourse-and applies this broader conception to reach the conclusion (with which I agree) that there can be global public discourse, even without successful global institutions (citing his own disagreements with the pessimism of John Rawls and Thomas Nagel (p. 328)). Sen makes a case for a 'global intellectual history of public participation' (pp. 32 I-54) in political and social decision-making, citing ancient Buddhist councils and texts in both India and Japan, and suggesting as well that the 'Western' tradition of democracy is not a unilinear development from classical Greek practice to the French Revolution or Mandela's new South African constitution, but should also include more participatory and inclusive forms of government in parts of the Middle East. Sen argues that democracy (in the form of a free press, public and populist protests, as well as critical parties and more organised institutions) is related positively to human development, flourishing and reduction of injustice. Like the oft misreported claim made by Thomas Friedman (I999) that no two nations who have a McDonald's have gone to war with each other (not true any more, if it ever was), Sen argues that famines (as in India, China, North Korea, the Soviet Union) are more likely to occur in authoritarian regimes rather than in places where populations can mobilise both 'reason' (through media reports of what is happening on the ground), and what I would argue is a more 'emotional' or value-based process of mass political protests, designed to call unjust regimes to public account for their misallocation of resources.

Based on his earlier work in Identity and Violence: The Illusion of Destiny (2006), Sen also makes a compelling case for the enhancement of human security and safety in those places where identity is acknowledged to be plural (where we are members of religions, communities, occupations, ethnicities, nationalities, classes and genders), all of which should diversify our loyalties, and move us towards not only tolerance, but recognition that we are all subject to many different affiliations and appeals to what is right. (In my third sphere of discourse, based on values and emotions, not all is 'rational' in that neutral reasoned sort of way. The communitarian philosophers, like Sandel, also disclaim neutrality in this sphere. ${ }^{22}$ ) Sen argues, persuasively, that to the extent that societies, nations and all political groupings can be inclusive of minority as well as majority groups (a category which is demographically changing in the two places I have most recently inhabited - London and California), there will be a diversity of ideas, and respect for many ways of doing things. He is optimistic that this will also lead to more, not less, personal security, and recognition of human rights. In addition, Sen seeks to base a description of modern human rights not exclusively on law or legal entitlements but on moral, ethical precepts (which some critics might suggest returns him to a more 'transcendental or universal' assumption about what these are). Alternatively, these could be derived from the third sphere of emotional, value-based or religious commitments.

Thus, while I agree with most of Sen's arguments for plural objectivity and comparisons, I part company with Sen in his sentence in his final chapter that 'outrage can be used to motivate, rather than to replace reasoning' (p. 389). If political choices and outcomes are plural and should be evaluated in their 'comparative realization' then so too should the processes we use to deliberate publicly about the amelioration of injustice. Martin Luther King's civil rights struggle was largely based on Christian values (as was Mandela's and Tutu's claims against apartheid in South Africa), and feminists used anger (as well as withholding of domestic services and hunger strikes) to inspire sympathy and demand social and political rights. Currently, refugees all over the world (as well as tortured detainees), appeal not only to our reason, but to our emotions and

22 See note 29 . 
I70 | CÉSAR ARJONA et al.

humanity to combat what they experience as injustice, as they try to persuade the rest of the global community to right these wrongs with whatever means they can (international conventions and law, economic boycotts, pictures, films and other representations), intended to pull both at our heartstrings and at our sense of ethical 'fellow-feeling' (an approach to justice or injustice that is based as much on empathy, the Golden Rule, and 'there but for the grace of God go I', as on our ability to reason).

So my basic critique of an otherwise inspiring and agenda-setting work of remarkable interdisciplinary breadth is to ask: If, as Sen suggests, we must have a 'plurality of reasons', a variety of partial rankings and a selection of possible resolutions for relative or comparative reductions of injustice (pp. 394-400), why shouldn't the 'comparative framework' also include a plurality of processes and appeals to different features of the sources of human deliberation (rational, instrumental and needs based, and emotional, ethical or value based), instead of being assigned to purely 'transcendental' reason, when we recognise that even with the use of reason, we will not always agree on what routes to pursue?

My final comments concern how we can take Sen's work really seriously - how might we implement his programme of engaging in evaluations of 'comparative realizations' of efforts to reduce injustice? Here at our international legal programme at the Center of Transnational Legal Studies, we have asked, how would Sen construct our curriculum so that students from different legal and national cultures might engage in global justice problem-solving? Our responses have included not only multinational discussion of many of the substantive issues Sen asks us to consider (p. 409) - trade agreements, global health initiatives, ecology and environmental issues, debt, war, refugees, the role of religion and identity in different social and legal spheres to name but a few - but we have also tried (and will continue to do more) to use a variety of international (or 'transnational' as we prefer to say) modes or processes of learning and legal problem-solving.

We believe that multidisciplinary (law, economics, ethics, anthropology, psychology, sociology, political theory) study, not simple legal doctrine (whether civil codes or common law cases), should be the norm and not the exception, and we believe that virtually every subject should be taught comparatively, so that no single legal or other solution should be considered to be 'given' they are all 'chosen' against different cultural, legal, economic or other background assumptions.

We attempt to use different processes to study these issues - social interaction, internationally diverse classes (so far with fourteen countries and many more nationalities and affiliations of students), group and practice exercises, in addition to conventional lectures or Socratic dialogue. Students hear what other legal and political systems have tried and found successful or wanting. They learn from each other in the interstices of the formal and informal activities through which they learn (including films, as well as texts) about different parts of the world and different illustrations of how injustice is manifested in the world.

Although we haven't done it yet, I would add more explicitly some of the evaluative methods suggested by Sen's work - rigorous empirical tools (statistical analysis, game and decision theory, economics, organisational development and evaluation criteria) 23 that can be used to assess (and critique assessments of) successes and particular measures (e.g. what standards do global institutions like the World Bank and the IMF use to assess economic achievement and now governmental viability?).

I would also add study of those other domains I have alluded to above - how are non-rational, more emotional, value-based or bargained-for campaigns for justice conducted? So we do study the nongovernmental 'networks' (Slaughter, 2005) that are affecting 'global dialogue' in the form of NGOs, transgovernmental or subgovernmental affiliations and work groups, and we should do rigorous

23 I have made many of these suggestions for legal education generally, whether in the domestic or transnational context (Menkel-Meadow, 2007; 201 Ia). 
case-study analysis of both successful and unsuccessful efforts at injustice reduction in different parts of the world. ${ }^{24}$

I close my portion of this review with two narratives which I hope will appeal to more than just the 'reason' of the readership. In the opening of his book From Beirut to Jerusalem (I988), American journalist Thomas Friedman described his master's degree in Middle Eastern studies at Oxford in the late I970s as a place and time in which graduate students from all over that region and the world studied and dined together. He thought and dreamed that this new generation, educated together, would forge new alliances, and peace in the region, from both their intellectual studies and new personal relations, created across divisive and conflictual national borders. Although so far this vision has not achieved reality (it came close with the Oslo Accords and the historic Rabin-Arafat treaty signing), this vision is still mine.

So imagine the possibilities when, in our transnational legal studies programme at the Center for Transnational Legal Studies, the German and Israeli students bond over their studies and go off to pubs, movies and dinner dates together to discuss world issues and their new friendships forged in the aftermath of World War II, of which none of them have any personal experience (except for parental or grandparental stories), and when one Muslim and one Jewish student describe for the rest of the class their 'similar' religious observances (at the same time of year) of a month (Ramadan) or day (Yom Kippur) of atonement and forgiveness, and then (after both fasting) share home-made foods that represent their cultural observances. Will these two incidents, of many possible ones I could recount here, make world peace or even more global justice? Maybe not by themselves, but with 'transnational' plural legal education that draws on reason (with logic and comparison), bargaining (cultural negotiations to live and work together), and both shared and contentious appeals to emotions, ethics, values (across friendships and contested arguments), I hope we are building the sort of non-transcendental, but transnational, institution that can foster analysis of 'comparative realizations' of justice and new pluralistic ideas of how to actually reduce the amount of injustice in this world. Like Professor Sen, we do not have all the answers, or a perfectly flawless institution that could be a model for all other educational institutions, but we are grappling, in a pluralistic culture, ${ }^{25}$ with ways to understand more diverse ideas of what justice could be.

ARIF A. JAMAL: In beginning to write my contribution to this review, I am reminded of that old story of the blind men encountering the elephant. Each of them touches a different part of the creature, and as they explore it in this way, each develops a different sense of what the elephant actually is: a big tree-trunk-like creature (the leg), a long flexible hose-like thing (the trunk), etc.; we all know the story. Of course, the point is that things can appear different - even fundamentally so - depending on how one engages with them, what perspectives one uses, what bits one sees (or touches!). At its best, the story is an important parable for intellectual modesty in the face of personal perspectives which may actually be rather parochial, even if, individually, we do not always realise the

24 For example, although, as of the time of writing, the Obama Health Care reforms have finally passed through Congress, efforts to use deliberative democratic processes such as town hall meetings were not effective and were co-opted and disrupted by those seeking to oppose those reforms. Was that effective deliberative democracy to reduce injustice (see Menkel-Meadow, 20I Ib)? On the other hand, demonstrations at WTO and World Bank meetings (by environmental, labour and anti-poverty activists) do seem to have had some effects on agenda setting and outcomes at those global institutions.

25 And as I write this, we seek to become even more pluralistic. Our current students and faculty come from Asia, North, Central and South America (but only parts of these continents), Australia, Europe (UK, Spain, Italy, France, Germany, Portugal) and Israel. We are seeking to expand to include more students from the Middle East and Africa. We are located in London, where we can confront, discuss and critique hegemonic empires, languages, legal and economic orders, as we live in one of the most diverse cities in the modern world. 
I72 CÉSAR ARJONA et al.

limitations of our own vantage points. Furthermore, the parable reminds us of the importance of being open to other ways of engaging with a topic and how we might glean a better, and indeed perhaps even more accurate, understanding of the 'whole' by considering how it is experienced by others. I invoke this story at the beginning because I have been much enriched by the perspectives brought to the task of this essay by my fellow reviewers. In our discussions and through the circulation of drafts, I have been able to see that my way of encountering the elephant is only one of several options. I want to return, at the end, to some further thoughts about the significance of this process, but I begin by building on the work of my fellow reviewers.

Colleagues have rightly emphasised several of the considerable strengths and insights proved by Sen's The Idea of Justice. I would like, first, to add to what they have noted by highlighting more of what I will call Sen's very valuable 'commissions'. I will, however, move on to consider what I think Sen fails to give us - his 'omissions' - so that I will ultimately argue that while Sen provides a persuasive and elegant critique of Rawls's A Theory of Justice, he does not take up the challenge that Rawls did in Political Liberalism (1993).

As part of the challenge to transcendentalism, Sen emphasises his departure from theories about the 'just society' in favour of a theory that concentrates on 'realization-based comparisons' that focus on the advancement or retreat of justice' (p. 8). In other words, there may be instances, as Sen puts it, of 'remediable injustice' (p. x), particularly those we may be able to understand from a comparative perspective. Sen argues passionately and compellingly that we must address these instances even if we cannot develop a full sense of the just society. Sen thus makes a powerful case for the value of an incremental approach to justice consisting, whenever possible, of a series of justice-enhancing steps because '[j]ustice is ultimately connected with the way people's lives go, and not merely with the nature of the institutions surrounding them' (p. x). Additionally, (part of) the point of the niti/ nyaya distinction that Sen derives from classical Indian jurisprudence, is nyaya's emphasis on realised justice (p. 20). As Victor Ramraj has noted, the emphasis on incrementalism resonates with Voltaire's caution not to make the best an enemy of the good.

The second of Sen's commissions that I wish to highlight is the emphasis on engagement. César Arjona comments on the practical, grounded approach that Sen employs and finds in this a Marxist dimension to The Idea of Justice. This conclusion seems both perfectly reasonable and entirely consistent with other parts of Sen's oeuvre. Whether this is a Marxist dimension or not, however, what I wish to emphasise is the significant remedial contribution Sen's engaged focus makes to discussions of justice. Theorising about justice often takes place at levels of reified abstraction. Sen calls this level the 'transcendental', and he pulls us - indeed appears to want to compel us - to focus on realising justice 'in the real world' rather than just in our theoretical constructions. Of course, Sen is not alone in urging this focus. In a similar vein, within legal philosophy, Ronald Dworkin has criticised jurisprudential thinking that is 'Archimedean' (2004). Dworkin's main target is of course the legal philosopher H. L. A. Hart. Hart says in The Concept of Law that his is a work of 'descriptive sociology' (I997, p. vi), elaborating further that his account is 'descriptive in that it is morally neutral and has no justificatory aims' (p. 240, emphasis in original). ${ }^{26}$ In a justifiably famous and rather moving passage Ronald Dworkin responds to this Hartian perspective:

'On occasions like this one it is hard to resist speaking directly to young scholars who have not yet joined a doctrinal army. So I close with this to those of you who plan to take up legal philosophy.

26 One can note the parallels in Hart's outlook (on the concept of law) and Rawls's outlook in A Theory of Justice (on the concept of justice) when Rawls says (I999a, p. 6): 'For us the primary subject of justice is the basic structure of society, or more exactly, the way in which the major social institutions distribute fundamental rights and duties and determine the division of advantages from social cooperation.' 
SENSES OF SEN: REFLECTIONS ON AMARTYA SEN'S IDEAS OF JUSTICE $\mid$ I73

When you do, take up philosophy's rightful burdens, and abandon the cloak of neutrality. Speak for Mrs Sorenson [a hypothetical plaintiff] and for all the others whose fate depends on novel claims about what the law already is. Or, if you can't speak for them, at least speak to them, and explain why they have no right to what they ask ... Speak to lawyers and judges who must puzzle about what to do with the [then] new [UK] Human Rights Act. Don't tell judges that they should exercise their discretion as they think best. They want to know how to understand the Act as law, how to decide, and from what record, how freedom and equality have now been made not just political ideals but legal rights. If you help them, if you speak to the world in this way, then you will remain more true to Herbert Hart's genius and passion than if you follow his narrower ideas about the character and limits of analytical jurisprudence.' (2004, p. 37)

Clearly, Dworkin is reacting strongly against theorising in a transcendent/Archimedean way in the above, and calling for a legal theory that is engaged with real-life, practical issues, cases and parties. Indeed, Dworkin may be seen to have the advantage, as theorists of law do, of being able to invoke specific legal cases or legislation as moments for justice. Sen, however, makes us aware that even theorists of justice may take this approach, always keeping their focus on engagement with the real issues and problems, and on providing the most just solutions for these specific concerns.

Finally, Sen's work contributes a methodology by which to assess engagement and, even more, incremental improvement. For Sen, this can be done through his 'capability approach' (see Part III generally and pp. 23Iff. especially), wherein 'individual advantage is judged ... by a person's capability to do things he or she has a reason to value' (p. 23I). Capability is supremely engaged since it relates to the capacity practically to do things, rather than relying on abstract conditions of justice. At the same time, capability is also able to account for incremental improvement because any increase in capability, even of a modest form, is a step towards a realisation of justice. That is to say, capability can be enhanced by non-perfect ameliorations - resulting in conditions that are better than they were before, even if not ideal - and, therefore, is willing to take seriously small steps towards justice. Thus, Sen's focus on incrementalism, engagement and capability together form an integrated framework which challenges abstract and perfection-dependent classical conceptions of justice: he 'seasons justice' not with Portia's plea for mercy ${ }^{27}$ but with the economist's eye for moves towards its practical realisation. For this, Sen's work is a salient moment in thinking about justice.

For all of the success Sen has in challenging transcendental conceptions of justice, however, and in particular Rawls's formulation, The Idea of Justice can be critiqued for its omissions. Sen places great stock in our deliberations about justice and its elements such as equality and fairness, and acknowledges that we will have plural perspectives about these concepts. Most notably, this means, as Sen recognises, that we may have fundamental disagreements about and around these concepts, and even that we may struggle to order our priorities about them as individuals:

'If the importance of public reasoning has been one of the major concerns of this book, so has been the need to accept the plurality of reasons that may be sensibly accommodated in an exercise of evaluation. The reasons may sometimes compete with each other in persuading us in one direction or another in a particular assessment, and when they yield conflicting judgments, there is an important challenge in determining what credible conclusions can be derived after considering all of the arguments.' (p. 394)

27 'When mercy seasons justice' - The Merchant of Venice. Act IV, Sc. I (see also Menkel-Meadow, I985). 
I74 | CÉSAR ARJONA et al.

And, further:

'The plurality of reasons that a theory of justice has to accommodate relates not only to the diversity of objects of value that the theory recognizes as significant, but also to the type of concerns for which the theory might make room, for example, on the importance of different kinds of equality or liberty. Judgments about justice have to take on board the task of accommodating different kinds of reasons and evaluative concerns. The recognition that we can often prioritize and order the relative importance of competing considerations does not, however, indicate that alternative scenarios can always be completely ordered, even by the same person.' (p. 395)

Having noted this basic and fundamental challenge that any theory of justice must address, Sen's great omission, in my view, is that he does not provide us with a very substantial account of how we might resolve our different evaluations of justice and its constituents. What Sen does is argue that

'considerable heterogeneity of perspectives can be accommodated internally within a capacious theory, generating partially complete rankings which help to separate out plausible decisions (if not the 'best' decision) from clearly rejected proposals.' (p. 397, emphasis in original)

Sen, however, does not appear to go further than this. While he does emphasise, quite reasonably, that a broad political theory that makes room for 'non-congruent' considerations does not make the theory necessarily incoherent or, indeed, useless, the notion of a capacious theory seems to be the limit of Sen's theorising about how we might deal with plural conceptions of justice and its elements. But is this enough? Might we not insist that Sen take up more robustly the task he has articulated himself - the task of accommodating different kinds of reasons and evaluative concerns? Sen's omission in this regard is particularly notable in the light of the effort John Rawls has made in Political Liberalism precisely to provide us with this.

Famously, it is Rawls's contention that in dealing with our diversity

'. . we are to appeal only to presently accepted general beliefs and forms of reasoning found in common sense, and the methods and conclusions of science when these are not controversial... we are not to appeal to comprehensive religious and philosophical doctrines - to what we as individuals see as the whole truth - or to elaborate economic theories of general equilibrium, say, if these are in dispute.' (I993, p. 224; see also Rawls, I997)

This outlook has been called the 'standard approach' (Weithman, 2002) of liberalism and is the basis of that particular type of reasoning in public life that Rawls terms 'public reason', to which Sen refers. At the heart of public reason is the idea that since our comprehensive doctrines are varied, they cannot be endorsed by citizens generally and so cannot serve as the basis for our collective deliberations and decisions. What we need instead is a way to determine another basis for society, and for this we require a type of reasoning that does not rely on our comprehensive doctrines. Public reason, to be clear, is only designed to deal with matters that are public inasmuch as they have broad effect. For Rawls, public reason applies to constitutional essentials and basic questions of justice, including the basic structure of a society's main political, economic and social institutions and how they fit together (I993, p. II). Public reason would address these public matters through principles and values that are independent of comprehensive doctrines, and that all citizens can endorse. Through this, one will achieve free and willing assent to a political consensus - what Rawls called an 'overlapping consensus' - and therefore to a stable society (I987; I993). By overlapping consensus Rawls means a consensus that is at the same time affirmed 
by holders of different, opposing religious, philosophical and moral doctrines (I987, p. I), but that is not formulated in terms of general, comprehensive religious, philosophical or moral doctrines but rather in terms of certain fundamental intuitive ideas viewed as latent in the public political culture of democratic society (p. 6).

Of course, Rawls's formulation has been criticised by many commentators, not least Jürgen Habermas. ${ }^{28}$ Nonetheless, through public reason, Rawls aims to provide us with a mechanism by which we might resolve our differences of opinion about, inter alia, what justice demands or, to use Sen's terms, resolve our plural conceptions into some form of political consensus. But we do not seem to get a comparable methodology in Sen's work. For example, it remains unclear how we might decide on conditions of enhanced or decreased capability if we disagree about what level of capability is reflected by different factual circumstances. That is to say, how do we resolve different assessments of capability itself? Sen gives the example of a disabled person who cannot do certain things by herself and considers her situation in three cases: (I) where she is not helped by others and therefore cannot go out of her house; (2) where she is helped by others either voluntarily or through a social security system and therefore can move about freely; and (3) where she has well-remunerated servants who obey her commands so is again able to move about freely. Sen holds that "in terms of "capability", as defined in the capability approach, cases (2) and (3) are largely similar as far as the disabled person is concerned' (p. 306). At first blush, we might think this a perfectly reasonable position to take, but what if the disabled person thought differently? What if she thought her capability was better in case (2) or if, more generally, when it came to making decisions collectively within any political community there was disagreement about whether capability conditions were higher in case (2) or case (3) such that some would argue that the political community should seek to achieve more case (2) results and others more case (3) results? How would we deal with such a plurality of assessment? Sen (p. 398) astutely notes that we can still be well served by incomplete rankings of alternatives or agreed partial rankings, but what if we cannot achieve even these? This is where Rawls's theory makes such a valuable contribution, because it tells us - not uncontroversially, of course - what reasons we can legitimately employ in public political debate precisely to formulate policy choices between different outlooks. Sen's alternative capacious theory, however, which admirably wants to make room for our plural perspectives, does not seem to give us much comfort in dealing with clashes between and amongst these perspectives.

Sen's outlook may better serve us however when we think of justice transnationally. When Rawls turned his attention to 'international justice' in The Law of Peoples he was roundly criticised for, amongst other things, failing to take account of poverty, inequalities and the environment; 29 in short, for being far too parochial, and blind to the different demands and conditions that arise in different contexts. The capability approach represents a change from a conception of justice in abstraction to one based on perceivable on-the-ground improvement. This might be more suitable when we think outside the contexts of advanced industrial economies domestically, but even more so when we think of justice across national contexts. Transnationally, we must be concerned with the pressing demands of environmental impacts which threaten not just the livelihood but even the very existence of some states, as well as with the impact of disabling poverty (and hence with distributional concerns). Sen provides us with the tools for keeping these concerns firmly in

28 In addition to the references to Habermas's works provided by Sen, see also Habermas (2006), where Habermas critiques the way in which Rawls's 'public reason' deals with religious convictions.

29 For critiques of Rawls see, for example, the Symposium (2000); Pogge (200I); Twining (2009, pp. I59-60): 'In my view The Law of Peoples is not worthy of the author of A Theory of Justice and is best forgotten.' But see, in Rawls's defence, Freeman (2007). Martin and Reidy (2006) offer a series of essays, some criticising, some defending, Rawls's work. 
I76 CÉSAR ARJONA et al.

mind. Transnational perspectives, however, will almost certainly only add complexity to our notions of justice and in so doing may make the need for a metric to resolve competing visions even more important. And here Sen's theory does not furnish much assistance.

In part, this may be Sen's (implicit?) point. He talks approvingly about widely accepted political notions of democracy as 'government by discussion' (pp. 324-26), and perhaps this is his paradigm for justice too. In this manner, Sen's idea may be that justice is best understood conversationally, a theme which Carrie Menkel-Meadow ably explores in her contribution. Indeed, what makes Sen's theory compelling, in spite of the omission that I charge it with, is the way in which it seeks to capture our different conversations about justice.

All of this brings me back to the idea of the elephant that I mentioned earlier. As we sat around a table discussing and debating The Idea of Justice, it seemed to me that we were often like the blind men (and women!) encountering the elephant. Each of us encountered the work in our own way, informed by our own perspectives. I was enriched by reading this important work in the company, as it were, of others who disclosed parts of 'the elephant' that would have been hidden to me if I had been left to my own devices, and I hope I was able to return the compliment. Ultimately, one of Sen's major points may be that our sense(s) of justice will likewise be improved by always adopting a conversational and practically minded, rather than transcendent, approach to the idea of justice.

\section{References}

ARrow, Kenneth J. (I96I) Social Choice and Individual Values, 2nd edn. New York: Wiley. CONDORCET, Nicolas de (I998) Esquisse d'un tableau historique des progrès de l'esprit humain. Paris: Flammarion.

Cutler, A. Claire (2003) Private Power and Global Authority: Transnational Merchant Law in the Global

Political Economy. Cambridge: Cambridge University Press.

DHARma, Krishna (ed.) (I999) Mahabharata: The Greatest Spiritual Epic of All Time. Canada: Torchlight

Publishing.

DWORKIN, Ronald (2004) 'Hart's Postscript and the Character of Political Philosophy', Oxford Journal of

Legal Studies 24: I-37.

ELSTER, Jon (I995) 'Strategic Uses of Argument', in Kenneth Arrow, Robert H. Mnookin, Lee Ross, Amos Tversky and Robert Wilson (eds), Barriers to Conflict Resolution. New York: W. W. Norton and Company, 236-57.

FISHER, William, REED, Thomas and Horwitz, Morton (eds) (I993) American Legal Realism. Oxford: Oxford University Press.

FORESTER, John (2009) Dealing with Differences: Dramas of Mediating Public Disputes. Oxford: Oxford

University Press.

FREEMAN, Samuel (2007) Rawls. London: Routledge.

fRIEdman, Thomas (I988) From Beirut to Jerusalem: One Man's Middle Eastern Odyssey. London:

HarperCollins.

fRIEDman, Thomas (I999) The Lexus and the Olive Tree. New York: Random House.

fuller, Lon L. (200I) The Principles of Social Order, ed. Kenneth Winston. Oxford: Hart Publishing.

gutmann, Amy and thompson, Dennis (1998) Democracy and Disagreement. Cambridge, MA: Harvard

University Press.

Gutmann, Amy and thompson, Dennis (2004) Why Deliberative Democracy? Princeton: Princeton

University Press.

HABERMAS, Jürgen (2006) 'Religion in the Public Sphere', European Journal of Philosophy I4: I-25.

HABIB, Irfan (ed.) (I 997) Akbar and His India. Delhi/New York: Oxford University Press.

HAMPSHIRE, Stuart (200I) Justice is Conflict. Princeton: Princeton University Press. 
SENSES OF SEN: REFLECTIONS ON AMARTYA SEN'S IDEAS OF JUSTICE $\mid$ I77

HARDIng, Sandra (2003) The Racial Economy of Science: Toward a Democratic Future (Race, Gender and Science). Bloomington: Indiana University Press.

HART, H. L. A. (I997) The Concept of Law. Oxford: Oxford University Press.

Hume, David (I978) A Treatise of Human Nature, ed. L. A. Selby-Bigge and P. H. Nidditch. Oxford: Oxford

University Press.

Kelsen, Hans (I945) General Theory of Law and State. Cambridge, MA: Harvard University Press.

KRISCH, Nico (2010) Beyond Constitutionalism: The Pluralist Structure of Postnational Law. Oxford: Oxford

University Press.

Kunn, Thomas S. (I962) The Structure of Scientific Revolutions. Chicago: University of Chicago Press.

MANu (1991) the laws of manu, ed. Wendy Doniger. London: Penguin Books.

martin, Rex and ReIDy, David A. (eds) (2006) Rawls's Law of Peoples: A Realistic Utopia? Malden, MA:

Blackwell.

Mattei, Ugo (I997) 'Three Patterns of Law: Taxonomy and Change in the World's Legal Systems',

American Journal of Comparative Law 45: 5-44.

MENKEL-MEAdow, Carrie (I985) 'Portia in a Different Voice: Speculations on a Women's Lawyering

Process', Berkeley Women's Law Journal i: 39-63.

MENKEL-MeAdow, Carrie (2004-2005) 'The Lawyer's Role(s) in Deliberative Democracy', Nevada Law

Review 5: 347-66.

MENKEL-MEADOW, Carrie (2006a) 'Peace and Justice: Notes on the Evolution and Purposes of Plural Legal

Processes', Georgetown Law Journal 94: 553-80.

MENKEL-MEADOW, Carrie (2006b) 'The Ethics of Compromise', in Andrea Kupfer Schneider and

Christopher Honeyman (eds), The Negotiator's Field Book: The Desk Reference for the Experienced

Negotiator. Washington, DC: American Bar Association, Section of Dispute Resolution, I55-64.

MENKEL-MEAdow, Carrie (2007) 'Taking Law and ... Really Seriously: Before, During and After the Law',

Vanderbilt Law Review 60: 555-95.

MeNKel-Meadow, Carrie (20ira) 'Why and How to Study Transnational Law', Irvine Law Review i: 97-I 28.

MENKEL-MEAdow, Carrie (20I Ib) 'Scaling Up Deliberative Democracy in Health Care Reform: A Work

in Progress', Law and Contemporary Problems 74: I-30.

Menski, Werner (2006) Comparative Law in a Global Context: The Legal Systems of Asia and Africa.

Cambridge: Cambridge University Press.

MENSKI, Werner (2007) 'Beyond Europe', in Esin Örücü and David Nelken (eds), Comparative Law: A

Handbook. Oxford/Portland, OR: Hart Publishing, I89-2 I6.

NAGEL, Thomas (I997) The Last Word. New York: Oxford University Press.

nussbaum, Martha (200I) Upheavals of Thought: The Intelligence of Emotions. Cambridge: Cambridge

University Press.

PASCAL, Blaise (I958) Pascal's Pensees. Available at: www.gutenberg.org/ebooks/ I 8269 (last accessed I7

April 20II).

POGGe, Thomas W. (200I) 'Rawls on International Justice', Philosophical Quarterly 51: 246-53.

POPPER, Karl R. (2002) The Logic of Scientific Discovery. London: Routledge.

pound, Roscoe (I9ro) 'Law in Books and Law in Action', American Law Review 44: I2-36.

RAWLS, John (I987) 'The Idea of an Overlapping Consensus', Oxford Journal of Legal Studies 7: I-25.

RAWls, John (I993) Political Liberalism. New York: Columbia University Press.

RAWLS, John (I997) 'The Idea of Public Reason Revisited', University of Chicago Law Review 64: 765-807.

RAwls, John (I999a) A Theory of Justice, rev. ed. Cambridge, MA: Belknap/Harvard University Press.

RAwls, John (I999b) The Law of Peoples. Cambridge, MA: Harvard University Press.

SANDEL, Michael J. (2009) Justice: What's the Right Thing to Do? London: Penguin Books.

SEN, Amartya (I985) Commodities and Capabilities. Amsterdam: North Holland.

SEN, Amartya (I993) Inequality Reexamined. Oxford: Clarendon Press. 
I78 $\mid$ CÉSAR ARJONA et al.

SEN, Amartya (I999) 'Autobiography', in Tore Frängsmyr (ed.), The Nobel Prizes I998. Stockholm: Nobel Foundation. Available at: www.nobelprize.org/nobel_prizes/economics/laureates/I998/ sen-autobio.html (last accessed I September 20I I).

SEN, Amartya (2005) The Argumentative Indian. London/Delhi: Penguin Books.

SEN, Amartya (2006) Identity and Violence: The Illusion of Destiny. London: Penguin Books.

SEn, Amartya (2009) A Conversation with Amartya Sen (and Richard Sennett). Available at: http://www2.

lse.ac.uk/publicEvents/events/2009_09-I2/2009I I 20tI 700vOT.aspx (last accessed I7 April 20I I).

SEN, Amartya (2010) 'The Economist Manifesto', New Statesman. Available at: www.newstatesman. com/ideas/2010/04/smith-market-essay-sentiments (last accessed i September 20I I).

SLAughter, Anne Marie (2005) A New World Order. Princeton: Princeton University Press.

SMITH, Adam (1976) An Inquiry into the Nature and Causes of The Wealth of Nations. Chicago: University of Chicago Press.

sмith, Adam (I976) The Theory of Moral Sentiments. London: Clarendon Press.

smith, Vincent (I909) Asoka: The Buddhist Emperor of India. Oxford: Clarendon Press.

summers, Robert S. (I982) Instrumentalism and American Legal Theory. Ithaca: Cornell University Press. SYMPOSIUM (2000) Ethics I Io.

Twining, William (2009) General Jurisprudence. Cambridge: Cambridge University Press.

VAN DE KERChOve, Michel and ost, François (I987) Jalons pour un théorie critique du droit. Bruxelles: Publications des Facultés Universitaires Saint-Louis.

voltAire (I772) La Bégueule. Available at: http://fr.wikisource.org/wiki/La_Bégueule (last accessed I7 April 2OII).

WEISBERG, Robert W. (2006) Creativity: Understanding Innovation in Problem Solving, Science, Invention and the Arts. New Jersey: Wiley.

weithman, Paul (2002) Religion and the Obligations of Citizenship. Cambridge: Cambridge University Press.

wiLson, Richard (2009) 'Western Europe: Last Holdout in the Worldwide Acceptance of Clinical Legal

Education', German Law Journal Io: 823-46.

yunnus, Muhammad (2003) Banker to the Poor. London: Aurum Press. 